\title{
MIND-BODY PRACTICE BY PERSONS WITH MULTIPLE SCLEROSIS
}

\author{
MERISANDA ČASAR ROVAZDI ${ }^{1}$, VIKTOR VIDOVIĆ ${ }^{2}$, SENKA RENDULIĆ SLIVAR ${ }^{3}$, OTO KRAML $^{4}$ \\ Lipik Special Hospital for Medical Rehabilitation, Lipik, Croatia ${ }^{1,2,3,4}$, kontakt: merisanda.casar@bolnica-lipik.hr
}

Recieved: 20.11.2015.

UDK: $615.8: 376.1-056.266$

Accepted: 15.1.2016.

Preliminary report

\begin{abstract}
The objectives of the study were to assess the prevalence of mind-body practice by persons with multiple sclerosis (MS) and analyze the relationship of age, sex, clinical course of MS, level of incapacity, and time elapsed from MS diagnosis. The study included 120 patients with MS who underwent inpatient rehabilitation at the Lipik Hospital for Medical Rehabilitation in the period from May 1, 2015 to October 10, 2015. For the purposes of the study, a semi-structured questionnaire on the current usage of mind-body procedures was applied. Closed ended questions referred to the use of the following procedures: meditation, deep-breathing exercises, hypnotherapy, yoga, biofeedback, chiropractic, massage, reflexology, bioenergy, and magnetic therapy. The studied patients were divided into two groups according to whether they practiced or did not practice mind-body procedures. Comparison of the variables was performed using Student's t-test and a Pearson correlation test. At the time of the study, 37 (30.8\%) MS patients reported currently practicing one or more mind-body procedures. Respondents most commonly were practicing meditation $(n=13 ; 10.8 \%)$, followed by massage $(n=10 ; 8.3 \%)$, acupuncture $(n=7 ; 5.8 \%)$, bioenergy healing $(n=7 ; 5.8 \%)$, magnetic therapy $(5 ; 4.2 \%)$, chiropractic $(n=5 ; 4.2 \%)$, yoga $(n=3 ; 2.5 \%)$, tai chi $(n=2 ; 1.7 \%)$, and reflexology $(n=1 ; 0.8 \%)$. There was no statistically significant difference according to age $(p=0.520)$, sex $(p=0.448)$, EDDS score $(p=0.489)$, disease duration $(p=0.963)$ and disease course $(p=0.932)$ between the groups of respondents practicing and those not practicing mind-body procedures. Regarding the widespread use of various mind-body procedures, there is a need to actively monitor MS patients in order to provide them with guidance when using these procedures.
\end{abstract}

Key words: multiple sclerosis, complementary and alternative medicine, mind-body procedures

\section{INTRODUCTION}

Complementary and alternative medicine (CAM) refers to a group of health care systems, practices, and treatments that are not considered to be part of conventional medicine (National Center of Complementary and Alternative Medicine, 2008). According to the National Center for Complementary and Alternative Medicine (NCCAM) (2008), CAM can be divided into five categories: (1) biologically based therapies, e.g., dietary supplements, various diets, herbs; (2) mindbody practices, e.g., meditation, deep-breathing exercises, tai chi, hypnotherapy, yoga, hypnosis, biofeedback, and imagery; (3) manipulative and body-based methods, e.g., chiropractic, massage, reflexology, osteopathic manipulations, and movement therapies; (4) energy therapies, e.g., Reiki, therapeutic touch, and magnetic therapy; and (5) alternative medical systems, e.g., traditional Chinese medicine, homeopathy, and naturopathy.
For research purposes, NCCAM (2008) recommends a modified classification of CAM because many of therapeutic approaches share a set of characteristics that create similar challenges in designing rigorous and definitive clinical investigation or their benefit and safety:

1. natural product approaches, e.g., herbs, vitamins and minerals, probiotics;

2. mind-body procedures; and

3. other complementary health approaches, e.g., practices of traditional healers, Ayurvedic medicine, traditional Chinese medicine, homeopathy, and naturopathy.

According to modified classification, mindbody procedures encompass interventions from the domains of mind and body practices, manipulative and body based practices, and energy medicine: yoga, chiropractic and osteopathic manipulation, meditation, massage therapy, acupuncture, relaxation techniques (e.g., breathing exercises, guided 
imagery, progressive muscle relaxation), tai chi, qigong, healing touch, magnetic therapy, reflexology, hypnotherapy, and movement therapies (e.g., Feldenkrais method, Alexander technique, and Pilates).

Multiple sclerosis (MS) is an inflammatory, demyelinating, neurodegenerative disorder of the central nervous system (CNS) of unknown etiology (Noseworthy et al., 2000). MS is characterized by CNS inflammation, demyelination, axonal injury, and axonal loss. It is believed to be an autoimmune disorder, but the antigen specificity of the immune response is unknown (Kamm et al., 2014). Across Europe, the mean annual incidence rate is about 4.3:100,000 (Pugliatti M et al., 2006). The peak onset is between age 20 and 40 years (Kurtzke et al., 1992, Liguori et al., 2000); women are affected approximately twice as often as men (Sadovnick et al.,1982, Wallin et al., 2004). Patients can experience a diverse array of symptoms including impaired mobility, sensory disturbance, chronic pain, fatigue, bladder and bowel dysfunction, depression, and cognitive impairment (Senders et al., 2012). There are four clinical phenotypes of MS (Lublin et al., 1996):

1. Relapsing-remitting MS (RRMS) is characterized by periods of clinical stability that are interrupted by relapses or attacks of MS during which patients experience clinical worsening (initially occurring in more than $80 \%$ of individuals with MS).

2. Secondary progressive MS (SPMS) follows a course of relapsing-remitting MS. It is characterized by steady worsening of symptoms with superimposed relapses in $40 \%$ of patients. Approximately half of all persons diagnosed with RRMS convert into the SPMS phenotype within a decade of the initial diagnosis.

3. Primary progressive MS (PPMS) is characterized by progressive worsening of the neurological symptoms from the onset of the disease (occurring in $10 \%-20 \%$ of individuals with MS).

4. Progressive relapsing MS (PRMS) is characterized by steady worsening of neurological function from the very beginning, in addition to occasional relapses like those experienced by people with RRMS (occurring in 5\% of MS patients).

The term "benign" MS is not an MS phenotype descriptor per se, but rather was intended to provide an indication of disease severity over time. Benign MS can only be diagnosed retrospectively, when there is little or no disability for a period of 10 to 15 years (Lublin et al., 2014). The diagnosis of MS is based on the demonstration of MS-typical CNS lesions disseminated in space and time based upon a combination of clinical and MRI findings (Polman et al., 2010). Treatments for MS are divided into two categories: disease modifying drugs to control the disease process (e.g., interferon beta, glatiramer acetate, teriflunomide, dimethyl fumarate, natalizumab, fingolimod, alemtuzumab, mitoxantrone), and methods to manage symptoms (Yadav et al., 2010). Since there is still no curative treatment, the majority of MS patients (up to $70 \%$ ) use various modalities of CAM (Yadav et al., 2010).

There have been several studies that estimated the effectiveness of various mind-body procedures in MS patients. Findings have shown that mindfulness meditation, yoga, and biofeedback had a positive effect on depression, anxiety, fatigue, quality of life, and bladder incontinence (Grossman et al., 2010, Oken et al., 2004, McClurg et al., 2006, Ghafari et al., 2009). Massage lowered anxiety, improved depressed mood, increased self-esteem and body image (Hernandez-Reif et al., 1998), and increased self-efficacy potentially resulting in better overall adjustment to the disease (Finch et al., 2014). Clinical trials of acupuncture use in MS patients were too limited to provide definitive information on effectiveness (Bowling, 2010).

The concept of human biofield has its origins in many different cultures over thousands of years with the development of numerous types of biofield therapies, e.g., Reiki, Healing Touch, Therapeutic Touch (Gronowicz et al., 2015), although scientific instruments have been unable to detect this energy. There is a lack of high-quality scientific studies of biofield therapies, but in a meta-analysis of 66 medium quality studies, Shamini and Mills (2010) found that biofield therapies showed strong evidence for reducing pain intensity in pain populations, and moderate evidence for reducing pain 
intensity in hospitalized and cancer populations, and decreased negative behavioral symptoms in dementia patients and anxiety in the hospitalized population; in conclusion, the authors state that there is a need for further high-quality studies in this area. The American Academy of Neurology (AAN) has recently published evidence-based guidelines estimating the effectiveness of various CAM modalities in MS patients (Yadav et al., 2014). They found the evidence insufficient to support or refute the effectiveness of the following treatment modalities from the mind-body group of procedures: mindfulness meditation, yoga, biofeedback, chiropractic, massage, acupuncture, and tai chi. Reflexology was possibly effective in reducing MS-associated paresthesia, and magnetic therapy was probably effective in fatigue.

\section{OBJECTIVES}

The objectives of the study were to assess the prevalence of mind-body procedure practice amongst MS patients and to analyze the relationship between procedure practicing and patient age, sex, clinical course of MS, level of incapacity, and time elapsed from MS diagnosis. In the study, a modified classification of CAM was used, as recommended for research purposes by NCCAM (2008).

\section{HYPOTHESES}

According to the results from previous studies and the objectives of the present one, we formulated the following hypotheses:

H1: The prevalence of mind-body procedure practice will be lower than the prevalence observed in other studies.

$\mathrm{H} 2$ : The prevalence of mind-body procedure practice will be influenced by sex, age, disease duration, and level of incapacity of the respondents.

Previous studies have shown that the frequency of usage of CAM is influenced by regional and cultural habits (Schwarz et al., 2008) as well as income level (Eisenberg et al., 1998, Foster et al., 2000). Furthermore, previous results have shown that users are predominantly female, have high- er levels of education, and report poorer health (Schwartz et al., 1999, Marrie et al., 2003, Nayak et al., 2003, Schwartz et al., 2008, Shinto et al., 2006).

\section{WORK METHODS}

The study included 120 MS patients who underwent inpatient rehabilitation at the Lipik Hospital for Medical Rehabilitation in the period from May 1, 2015 to October 10, 2015. Participating in the study were patients older than 18 who had been diagnosed with MS according to the revised McDonald criteria (Polman et al., 2010). The exclusion criterion was serious cognitive impairment. Data on patient age, sex, clinical course of MS, and time elapsed since MS diagnosis were collected. The degree of disability for all study subjects was based on the Expanded Disability Status Scale (EDSS) (Kurtzke et al., 1983), and the assessment of cognitive status was performed using the Mini Mental Status Exam (MMSE) (Folstein et al., 1975). For the purposes of the study, a semi-structured questionnaire on the current usage of mind-body procedures was applied. Closed ended questions referred to the following procedures: meditation, deep-breathing exercises, hypnotherapy, yoga, biofeedback, chiropractic, massage, reflexology, bioenergy, and magnetic therapy. The patients in the study were divided into two groups according to whether they practiced or did not practice mind-body procedures.

The study was approved by the Hospital Ethics Committee, and the patients were asked to provide written consent for participation in the study.

Statistical analysis was performed using SOFA Statistics. Comparison of the variables was conducted using Student's t-test and a Pearson correlation test.

\section{RESULTS}

The study included 120 patients, 90 (75\%) female and $30(25 \%)$ male, with a mean age of 51.6, an age range from 25 to 85 years. The mean time elapsed since MS diagnosis was 14.5 years, ranging from 6 months to 62 years. RRMS was experienced by 58 (48.3\%), SPMS by 57 (47.5\%), PPMS by $3(2.5 \%)$ and benign by $2(1.7 \%)$ patients. The mean EDSS was 5.2, ranging from 1.5 to 9 . At the time of the study, 37 (30.8\%) MS patients 
reported that they were currently practicing one or more mind-body procedures. A single procedure was used by 27 (73\%) and a combination of different modalities by 10 (27\%) subjects. The respondents were most commonly practicing meditation $(n=13 ; 10.8 \%)$, followed by massage $(n=10 ; 8.3 \%)$, acupuncture $(\mathrm{n}=7 ; 5.8 \%)$, bioenergy healing $(\mathrm{n}=7$; $5.8 \%)$, magnetic therapy $(5 ; 4.2 \%)$, chiropractic $(n=5 ; 4.2 \%)$, yoga $(n=3 ; 2.5 \%)$, tai chi $(n=2 ; 1.7 \%)$, and reflexology $(n=1 ; 0.8 \%)$ (Fig. 1$)$.

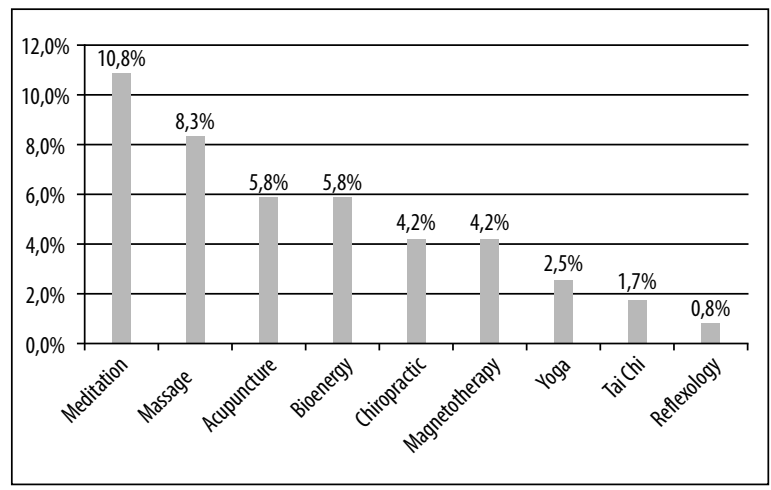

Fig. 1. Mind-body treatment modalities used by multiple sclerosis patients

Combinations of different modalities used by the respondents are shown in Figure 2.
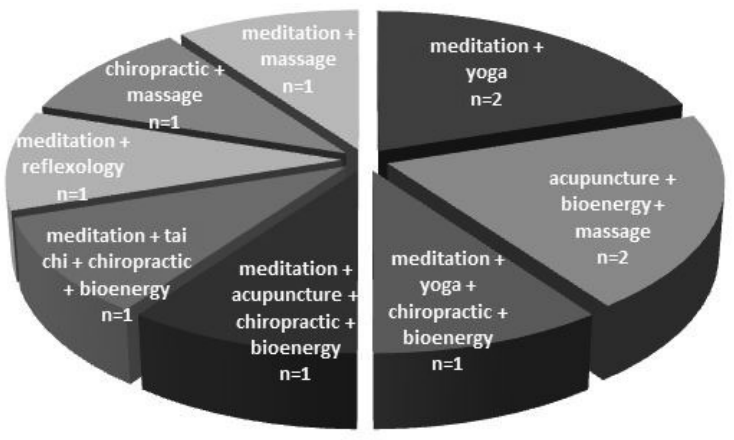

Fig.2. Mind-body treatment combinations used by multiple sclerosis patients $(n=10)$

The characteristics of respondents who were and who were not practicing mind-body procedures are shown in Table 1 . There was no statistically significant between-group difference according to age $(p=0.520), \operatorname{sex}(p=0.448)$, EDDS score $(p=0.489)$, disease duration $(\mathrm{p}=0.962)$, and disease course $(\mathrm{p}=0.932)$.

Table 1. Demographic and clinical characteristics of study patients

\begin{tabular}{|l|l|l|}
\hline Characteristic & $\begin{array}{l}\text { Mind- } \\
\text { body } \\
\text { procedure } \\
\text { users }\end{array}$ & $\begin{array}{l}\text { Mind- } \\
\text { body } \\
\text { procedure } \\
\text { non-users }\end{array}$ \\
\hline $\mathrm{n}(\%)$ & $37(30.8)$ & $83(69.2)$ \\
Age $(\mathrm{yrs}), \bar{X} \pm \mathrm{SD}$ & $52.6 \pm 12.39$ & $51.2 \pm 11.05$ \\
Female, $\mathrm{n}(\%)$ & $30(81.1)$ & $60(72.3)$ \\
Male, $\mathrm{n}(\%)$ & $7(18.9)$ & $23(27.7)$ \\
EDSS, $\bar{X} \pm \mathrm{SD}$ & $4.9 \pm 1.81$ & $5.2 \pm 1.95$ \\
MS course, $\mathrm{n}(\%) \mathrm{RRMS}$ & $18(48.7)$ & $40(48.2)$ \\
SPMS & $18(48.7)$ & $39(47.0)$ \\
PPMS & $0(0.0)$ & $3(3.6)$ \\
Benign MS & $1(2.6)$ & $1(1.2)$ \\
Time elapsed since MS & $14.6 \pm 10.53$ & $14.5 \pm 10.46$ \\
diagnosis $(\mathrm{yrs}), \bar{X} \pm \mathrm{SD}$ & \multicolumn{2}{|l}{} \\
\hline
\end{tabular}

EDSS = Expanded Disability Status Scale; MS $=$ multiple sclerosis; RRMS = relapsing- remitting multiple sclerosis; SPMS = secondary progressive multiple sclerosis; PPMS = primary progressive multiple sclerosis; Benign MS = benign multiple sclerosis

Due to a small number of patients with the PPMS and benign MS courses of the disease, statistical analysis was only done for patients with RRMS and SPMS when analyzing the relationship of procedure practice and course of the disease.

\section{DISCUSSION}

Studies on the use of CAM have documented the popularity of CAM for the treatment of health problems that lack definitive cures (Institute of Medicine US Committee on the Use of Complementary and Alternative Medicine by the American Public, 2005).The frequency of usage of CAM is influenced by regional and cultural habits (Schwarz et al., 2008), income level (Eisenberg et al., 1998, Foster et al., 2000), and insurance coverage of some CAM practices (e.g., chiropractors and massage therapists) (Wolsko et al., 2002). In a survey of 2,026 MS patients, 23\% were currently practicing yoga, and $16 \%$ meditation, which were the most popular mind and body treatment modalities (Yadav et al., 2006). In the study by Nayak 
et al. (2003), chiropractic manipulation was currently practiced by $25.5 \%$, massage by $23.3 \%$ and acupuncture by $19.9 \%$ of MS patients. Esmonde et al. (2008) analyzed the use of different CAM modalities in MS patients in the previous year and found that reflexology was practiced by $40 \%$, massage by $33 \%$, relaxation and meditation by $25 \%$, and chiropractic by less than $12 \%$ of the patients. The prevalence of practicing different mind-body modalities in five Nordic countries within the previous 12 months was as follows: yoga $7.8 \%-23 \%$, acupuncture $6.5 \%-20.8 \%$, meditation $5.9 \%-13 \%$, biofield energy healing $0.6 \%-12.2 \%$, and reflexology $1.5 \%-11.1 \%$, while less than $5 \%$ of the respondents used tai chi (Skovgaard et al., 2012).

The present study showed that $30.8 \%$ of MS patients currently practiced mind-body procedures. The patients most commonly were practicing meditation $(10.8 \%)$, followed by massage $(8.3 \%)$, acupuncture $(5.8 \%)$, and bioenergy treatment $(5.8 \%)$. Other modalities were utilized by less than $5 \%$ of the respondents. The only type of meditation practiced was mindfulness meditation, sport massage was the only type of massage utilized, and traditional Chinese acupuncture was the only type of acupuncture applied. All users of human biofield therapy stated they were treated with bioenergy, without specifying a particular method, such as healing touch or therapeutic touch.

Patients reporting that they practiced magnetic therapy used only magnetic gloves or bangles. The effectiveness of magnetic therapy applies only to bioelectromagnetic-based therapies using a verifiable electromagnetic field (Yadav et al., 2014), whereas wearing magnetic gloves or bangles is considered ineffective (National Center of Complementary and Alternative Medicine, 2008).

Our research findings showed a lower overall prevalence of mind-body procedures practiced among our respondents compared to respondents from other studies, but similar patterns in relation to the most popular mind-body modalities. The possible explanation for the lower overall rate of mind-body procedure usage is that the level of income plays an important role in whether a patient decides to start treatment with CAM. Moreover, unavailability of some treatment modalities of complementary and alternative therapy may be another reason for lower frequency of mind-body procedure practice among our patients. Previous studies did not analyze the link between mind-body procedure usage and disease related or epidemiological parameters, but studies investigating the utilization of all CAM modalities in MS patients (including dietary supplements and alternative medical systems) have shown that users are predominantly female, have higher levels of education, and report poorer health (Schwartz et al., 1999, Marrie et al., 2003, Nayak et al., 2003, Schwartz et al., 2008, Shinto et al., 2006). However, Apel et al. (2006) and Harirchian et al. (2014) found no statistically significant sex difference between CAM users and non-users, whereas Leong et al. (2009) and Berkman et al. (1999) found no difference according to the degree of incapacity. In most studies, CAM users had longer duration of illness than non-users (Apel et al., 2006, Skovgaard et al., 2012, Harirchian et al., 2014, Shinto et al., 2006), however, shorter MS duration was also observed among CAM users (Koch et al., 2014).

In the study by Skovgaard et al. (2013), CAM users were more likely to be $18-40$ years of age, whereas Harirchian et al. (2014) and Apel et al. (2006) found no age difference between CAM users and non-users.

In our study, there was no statistically significant between-group difference according to demographic or disease-related parameters. The heterogeneous findings reported in the literature could be due to different definitions of CAM, small sample size, and differences in the length of CAM practice (Schwartz et al.,2008). Moreover, our study had two limitations that made it difficult to compare it with other studies. Usage of CAM modalities other than mind-body procedures was not analyzed, and our respondents were MS patients who had been referred to inpatient rehabilitation. This means that the analysis excluded many of those with lesser functional deficit and shorter duration of the disease because these patients are rarely treated as inpatients. Despite these limitations, these research results indicate that awareness of suffering from a disease of a chronic progressive character such as MS leads to attempts to slow down the occurrence of new deficits, irrespective of age, sex, or degree of disability. 


\section{CONCLUSION}

Our study revealed that slightly less than one-third of the MS patients who participated as respondents practiced various mind-body procedures. The prevalence of practicing was not influenced by demographic or disease-related parameters. Meditation, massage, acupuncture, and bioenergy healing were the most commonly used modalities. Regarding the widespread use of various mind-body procedures, there is a need for active monitoring of MS patients to provide guidance when using these procedures. 


\section{REFERENCES}

Apel A, Greim B, Konig N, Zettl UK (2006): Frequency of current utilisation of complementary and alternative medicine by patients with multiple sclerosis. J Neurol. 253, 1331-1336.

Berkman CS, Pignotti MG, Cavallo PH, Holland NJ (1999): Use of alternative treatments by people with multiple sclerosis. Neurorehabil Neural Repair, 13, 4, 243-254.

Bowling AC (2010): Unconventional medicine and multiple sclerosis; the role of conventional health providers. In: Lucchineti, CF, Hohlfeld R, eds. Multiple Sclerosis 3 (Blue Books of Neurology series). Philadelphia, PA: Saunders; pp. 355-370.

Eisenberg DM, Davis RB, Ettner SL, Appel S, Wilkey S, Van Rompay M, Kessler RC (1998): Trends in alternative medicine use in the United States, 1990-1997: results of a follow-up national survey. JAMA. 28, 18, 1569-1575.

Esmonde L, Long AF (2008): Complementary therapy use by persons with multiple sclerosis: benefits and research priorities. Complement Ther Clin Pract. 14, 3, 176-184.

Finch P, Bessonnette S (2014): A pragmatic investigation into the effects of massage therapy on the selfefficacy of multiple sclerosis clients. J Bodywork Mov Ther. 18, 1, 11-16.

Folstein MF, Folstein SE, McHugh PR (1975): Mini-Mental State, a practical method for grading the cognitive state of patients for the clinician. J Psychiatr Res. 12, 189-198.

Foster DF, Phillips RS, Hamel MB, Eisenberg DM (2000): Alternative medicine use in older Americans. J Am Geriatr Soc. $48,12,1560-1565$.

Ghafari S, Ahmadi F, Nabavi M, Anoshirvan K, Memarian R, Rafatbakhsh M. (2009): Effectiveness of applying progressive muscle relaxation technique on quality of life of patients with multiple sclerosis. J Clin Nurs. 18, 15, 2171-2179.

Gronowicz G, Secor ER Jr, Flynn JR, Jellison ER, Kuhn LT (2015): Therapeutic touch has significant effects on mouse breast cancer metastasis and immune responses but not primary tumor size. Evidence-Based Complementary and Alternative Medicine; Retrieved 31 May, 2015 from http://www.hindawi.com/journals/ecam/2015/926565/.

Grossman P, Kappos L, Gensicke H, et al. (2010): MS quality of life, depression, and fatigue improve after mindfulness training: a randomized trial. Neurology. 75, 13, 1141-1149.

Harirchian MH, Sahraian MA, Hosseinkhani A, Amirzargar N (2014): Level of attitude toward complementary and alternative medicine among Iranian patients with multiple sclerosis. Iran J Neurol. 13, 13-18.

Hernandez-Reif M, Field TI, Field TO, Theakson H (1998): Multiple sclerosis patients benefit from massage therapy, Journal of Bodywork and Movement Therapies. 2, 168-174.

Institute of Medicine (US) Committee on the Use of Complementary and Alternative Medicine by the American Public (2005): Complementary and Alternative Medicine in the United States. Washington (DC): National Academies Press (US).

Kamm CP, Uitdehaag BM, Polman CH (2014): Multiple sclerosis: current knowledge and future outlook. Eur Neurol. $72,132-141$.

Kochs L, Wegener S, Sühnel A, Voigt K, Zettl UK (2014): The use of complementary and alternative medicine in patients with multiple sclerosis: a longitudinal study. Complement Ther Med. 22, 166-172.

Kurtzke JF (1983): Rating neurologic impairment in multiple sclerosis: an expanded disability status scale (EDSS). Neurology. 33, 1444-1452.

Kurtzke JF, Page WF, Murphy FM, Norman JE (1992): Epidemiology of multiple sclerosis in US veterans. Neuroepidemiology.11, 226-235.

Leong EM, Semple SJ, Angley M, Siebert W, Petkov J, McKinnon RA (2009): Complementary and alternative medicines and dietary interventions in multiple sclerosis: what is being used in South Australia and why? Complement Ther Med. 17, 4, 216-223. 
Liguori M, Marrosu MG, Pugliatti M, Giuliani F, De Robertis F, Cocco E, et al.(2000): Age at onset in multiple sclerosis. Neurol Sci. 21, S825-829.

Lublin FD, Reingold SC (1996): Defining the clinical course of multiple sclerosis: results of an international survey. National Multiple Sclerosis Society (USA) Advisory Committee on Clinical Trials of New Agents in Multiple Sclerosis. Neurology. 46, 907-911.

Lublin FD, Reingold SC, Cohen JA, Cutter GR, Sørensen PS, Thompson AJ, et al.(2014): Defining the clinical course of multiple sclerosis: the 2013 revisions. Neurology. 83, 278-286.

Marrie RA, Hadjmichael O, Vollmer T (2003): Predictors of alternative medicine use by multiple sclerosis patients. Mult Scler J. 9, 461-466.

McClurg D, Ashe RG, Marshall K, Lowe-Strong AS (2006): Comparison of pelvic floor muscle training, electromyography biofeedback, and neuromuscular electrical stimulation for bladder dysfunction in people with multiple sclerosis: a randomized pilot study. Neurourol Urodyn. 25, 4, 337-348.

Nayak S, Matheis RJ, Schoenberger NE, Shiflett SC (2003): Use of unconventional therapies by individuals with multiple sclerosis. Clin Rehabil. 17, 2, 181-191.

National Center of Complementary and Alternative Medicine ( NCCAM) (2008): What is complementary and alternative medicine (CAM)? Retrived 25 July, 2008 from http://nccam.nih.gov/

Noseworthy JH, Lucchinetti C, Rodriguez M, Weinshenker BG (2000): Multiple sclerosis. N Engl J Med. 343, 938-952.

Oken BS, Kishiyama S, Zajdel D, Bourdette D, Carlsen J, Haas M, et al. (2004): Randomized controlled trial of yoga and exercise in multiple sclerosis. Neurology. 62, 11, 2058-2064.

Polman CH, Reingold SC, Banwel B, Clanet M, Cohen JA, Filippi M, et al. (2011): Diagnostic criteria for multiple sclerosis: 2010 revision to the McDonald criteria. Ann Neurol. 69, 292-302.

Pugliatti M, Rosati G, Carton H, Riise T, Drulovic J, Vécsei L, et al.(2006): The epidemiology of multiple sclerosis in Europe (review). Eur J Neurol. 13, 700-722.

Sadovnick AD, Baird PA (1982): Sex ratio in offspring of patients with multiple sclerosis. N Engl J Med. 306, 11141115.

Schwartz S, Knorr C, Geiger H, Flachenecker P (2008): Complementary and alternative medicine for multiple sclerosis. Mult Scler J. 14, 8, 1113-1119.

Schwartz CE, Laitin E, Brotman S, LaRocca N (1999): Utilization of unconventional treatments by persons with MS: is it alternative or complementary? Neurology. 52, 626-629.

Senders A, Wahbeh H, Spain R, Shinto L (2012): Mind-Body Medicine for Multiple Sclerosis: A Systematic Review. Autoimmune Dis. 2012 Nov; 22 (4):e567324. doi:10.1155/2012/567324. PubMed PMID: 23227313; PubMedCentral PMC: 3512214.

Shamini J, Mills PJ (2010): Biofiled therapies: helpful of full of hype? A best evidence synthesis. Int J Behav Med. 17, 1, 1-16.

Shinto L, Yadav V, Morris C, Lapidus JA, Senders A, Bourdette D (2006): Demographic and health-related factors associated with complementary and alternative medicine (CAM) use in multiple sclerosis. Mult Scler J. 12, 94-100.

Skovgaard L, Nicolajsen PH, Pedersen E, Kant M, Fredrikson S, Verhoef M, et al. (2012): Use of complementary and alternative medicine among people with multiple sclerosis in the Nordic countries. Autoimmune Dis. Retrieved 11 Dec, 2012 from http://www.hindavi.com/journals/ad/2012/841085/.

Skovgaard L, Nicolajsen PH, Pedersen E, Kant M, Fredrikson S, Verhoef M, et al. (2013): Differences between users and non-users of complementary and alternative medicine among people with multiple sclerosis in Denmark: a comparison of descriptive characteristics. Scand J Public Health. 41, 492-499. 
Wallin MT, Page WF, Kurtzke JF (2004): Multiple sclerosis in US veterans of the Vietnam era and later military service: race, sex, and geography. Ann Neurol. 55, 65-71.

Wolsko PM, Eisenberg DM, Davis RB, Ettner SL, Phillips RS (2002): Insurance coverage, medical conditions, and visits to alternative medicine providers: results of a national survey. Arch Intern Med. 162, 3, 281-287.

Yadav V, Bever C Jr, Bowen J, Bowling A, Weinstock-Guttman B, Cameron M, et al. (2014): Summary of evidencebased guideline: complementary and alternative medicine in multiple sclerosis: report of the Guideline Development Subcommittee of the American Academy of Neurology. Neurology. 82, 12, 1083-1092.

Yadav V, Shinto L, Morris C, Senders A, Baldauf-Wagner S, Bourdette D (2006): Use and self-reported benefit of complementary and alternative medicine among multiple sclerosis patients. Int J Mult Scler Care. 8, 5-10.

Yadav V, Shinto L, Bourdette D (2010): Complementary and alternative medicine for the treatment of multiple sclerosis. Expert Rev Clin Immunol. 6, 381-395.

\section{PRIMJENA DUHOVNO-TJELESNIH TEHNIKA KOD OSOBA S MULTIPLOM SKLEROZOM}

Sažetak: Cilj istraživanja je bio utvrditi učestalost primjene duhovno-tjelesnih tehnika kod osoba s multiplom sklerozom (MS) i analizirati povezanost primjene tih tehnika s dobi, spolom, kliničkim tijekom MS, stupnjem onesposobljenosti i vremenom proteklim od postavljanja dijagnoze MS. Studijom je bilo obuhvaćeno 120 oboljelih koji su pohađali stacionarnu rehabilitaciju u Specijalnoj bolnici za medicinsku rehabilitaciju Lipik u periodu od 1.5.2015. do 10.10.2015.godine. U svrhu studije upotrijebljen je semi-strukturirani upitnik. Strukturiranim pitanjima ispitala se primjena sljedećih tehnika: meditacije, vježbi dubokog disanja, hipnoterapije, joge, biofeedbacka, kiropraktike, masaže, refleksologije, bioenergije i magnetoterapije. Ispitanici su podijeljeni u dvije skupine, ovisno o tome jesu li ili nisu primjenjivali duhovno-tjelesne tehnike. Usporedba varijabli učinjena je pomoću Studentovog t- testa i Pearsonovog testa korelacije. U vrijeme istraživanja 37 (30,8\%) ispitanika primjenjivalo je jednu ili više duhovno-tjelesnih tehnika. Ispitanici su najčešće primjenjivali meditaciju ( $n=13 ; 10,8 \%)$, potom masažu ( $n=10 ; 8,3 \%)$, akupunkturu $(n=7 ; 5,8 \%)$, bioenergiju ( $n=7 ; 5,8 \%)$, magnetoterapiju $(5 ; 4,2 \%)$, kiropraktiku $(n=5 ; 4,2 \%)$, jogu $(n=3 ; 2,5 \%)$, tai chi $(n=2$; $1,7 \%)$ i refleksologiju $(n=1 ; 0,8 \%)$. Između skupine koja je primjenjivala i koja nije primjenjivala duhovno-tjelesne tehnike nije nađena statistički značajna razlika u odnosu na dob, spol, EDSS zbroj, trajanje bolesti i klinički tijek bolesti. S obzirom na učestalu primjenu različitih duhovno-tjelesnih tehnika, potrebno je aktivno praćenje oboljelih od MS kako bi se mogle učiniti smjernice za liječenje navedenim tehnikama.

Ključne riječi: multipla skleroza, komplementarna i alternativna medicina, duhovno-tjelesne tehnike 